\title{
A Experimental Study on Partial Replacement of Cement with Metakaolin and Coarse Aggregate with Blast Furnace Slag
}

\author{
Shaik Fazlur Rahman \\ PG Student, \\ Dept. of Civil Engineering \\ Annamacharya Institute of Technology and Sciences \\ Kadapa, India
}

\author{
Smt. K Chandrakala \\ Assistant Professor, \\ Dept. of Civil Engineering \\ Annamacharya Institute of Technology and Sciences \\ Kadapa, India
}

\begin{abstract}
This paper presents results of an experimental investigation carried out to evaluate effects of replacing coarse aggregate with blast furnace slag and cement with metakaolin. Slag is a by product generated during manufacturing of pig iron and steel. Primarily the slag consists of calcium, magnesium, manganese and aluminium silicates in various combinations. The cooling process of slag is responsible mainly for generating different types of slags required for various end use consumers. The raw material in the manufacturing of metakaolin is Kaolin clay. The properties of metakaolin are very similar to the cement properties. Metakaolin is also a mineral admixture which converts calcium hydroxide into advantageous cementitious material. In this investigation we are going to replace $10 \%$ of cement with metakaolin and coarse aggregate with blast furnace slag with increasing percentages of $0 \%, 10 \%, 20 \%, 30 \%, 40 \%$. And we cast cubes and cylinders at various percentages of replacements and we can find the compressive and tensile strength of concrete.
\end{abstract}

\section{Keywords-Blast furnace slag,metakaolin}

\section{INTRODUCTION}

Concrete is a composite material composed of granular materials like coarse aggregates embedded in a matrix and bound together with cement or binder which fills the space between the particles and glues them together. Almost three quarters of the volume of concrete is composed of aggregates. To meet the global demand of concrete in the future, it is becoming a more challenging task to find suitable alternatives to natural aggregates for preparing concrete. Therefore the use of alternative sources for natural aggregates is becoming increasingly important. Slag is a co-product of the iron making process. Iron cannot be prepared in the blast furnace without the production of its co-product i.e. blast furnace slag.

The use of blast furnace slag aggregates in concrete by replacing natural aggregates is a most promising concept because its impact strength is more than the natural aggregate. Steel slag aggregates are already being used as aggregates in asphalt paving road mixes due to their mechanical strength, stiffness, porosity, wear resistance and water absorption capacity.

Materials which are using and their characteristic features

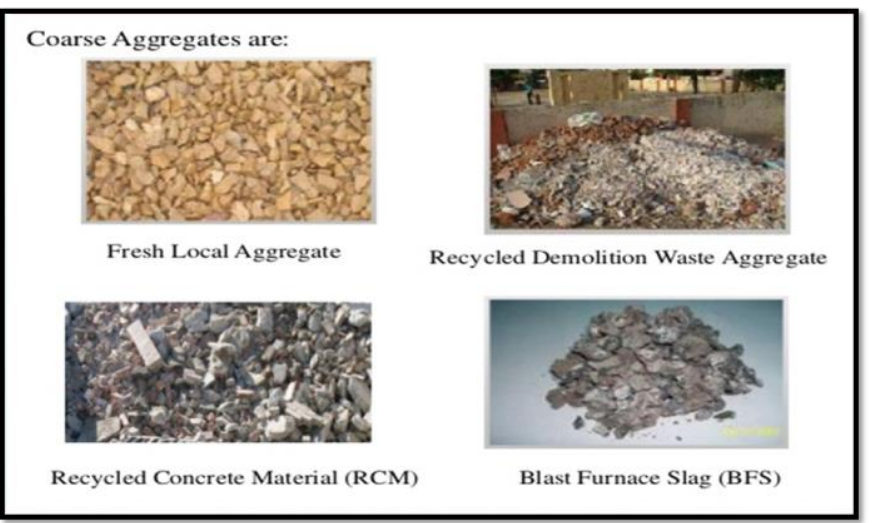

Fig. 1. various forms of coarse aggregate

Different types of slags find different uses in the industry. The air-cooled BF slag is crushed, screened and used mainly as road metal and bases, asphalt paving, railway ballast, landfills and concrete aggregate. The expanded or foamed slag binds well with cement and is used mainly as aggregate for light weight concrete. However, it is not produced by domestic steel plants. Granulated BF slag is used as a pozzolanic material for producing port land slag cement. It is also used for soil conditioning. BF slag is used in making mineral wool for insulation purposes. Steel slag has found use as a barrier material remedy for waste sites where heavy metals tend to leach into the surrounding environment. Steel slag forces the heavy metals to drop out of solution in water runoff because of its high oxide mineral content. Steel slag has been used successfully to treat acidic water discharges from abandoned mines.

Table I Chemical composition of blast furnace slag given below

\begin{tabular}{|c|c|}
\hline Component & Percentage (\%) \\
\hline Lime(Cao) & $30-40$ \\
\hline Silica(sio2) & $28-42$ \\
\hline Alumina(A12o3) & $5-22$ \\
\hline Magnesia(Mgo) & $5-15$ \\
\hline
\end{tabular}


The raw material in the manufacture of Metakaolin is kaolin clay

Heating up of clay with kaolinite $(\mathrm{Al} 2 \mathrm{O} 3.2 \mathrm{SiO} 2.2 \mathrm{H} 2 \mathrm{O})$ as the basic mineral component to the temperature of $500{ }^{\circ} \mathrm{C}-600^{\circ} \mathrm{C}$ causes loss of structural water with the result of deformation of crystalline structure of kaolinite and formation of an unhydrated reactive form - so-called metakaolinite. The chemical equations describing this process is

$$
\mathrm{Al} 2 \mathrm{O} 3.2 \mathrm{SiO} 2.2 \mathrm{H} 2 \mathrm{O}=\mathrm{A} 12 \mathrm{O} 3.2 \mathrm{SiO} 2+2 \mathrm{H} 2 \mathrm{O}(\mathrm{g})
$$

The use of pozzolanas for making concrete is considered efficient, as it allows the reduction of the cement consumption while improving the strength and durability properties of the concrete. Metakaolin when used as a partial replacement substance for cement in concrete, it reacts with $\mathrm{Ca}(\mathrm{OH}) 2$ one of the by-products of hydration reaction of cement and results in additional C-S-H gel which results in increased strength.

Cement replacement with MK $10 \%$ in content gave maximum enhancement in pore refinement of pastes and compressive strength reduces when MK addition goes beyond $30 \%$ as cement replacement. MK provides good resistance to aggressive chloride solution by consuming liberated obtained with OPC $-\mathrm{MK}$ blended cement mortars with $25 \%$ by weight of MK

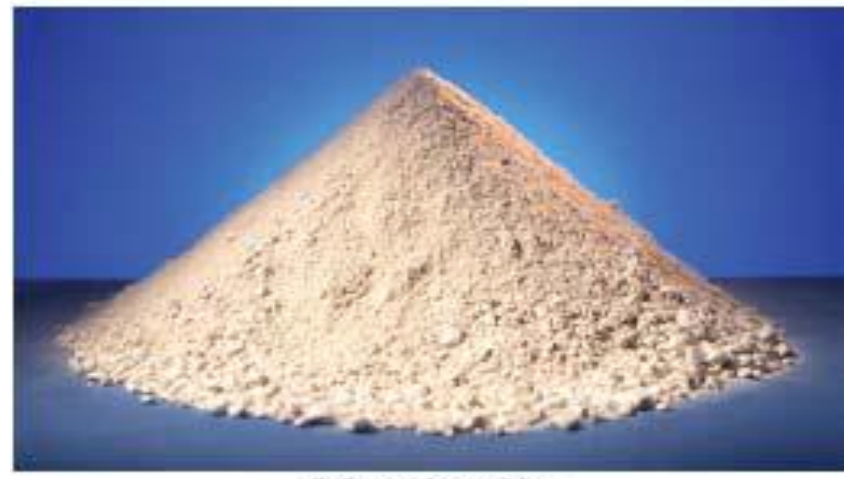

\section{Metakaolin}

Fig. 2. Metakaoline

\section{BACKGROUND AND MOTIVATION}

Perhaps the earliest known occurrence of cement was twelve million years ago. A deposit of cement was formed after an occurrence of oil shale located adjacent to a bed of lime stone burned due to natural causes these ancient deposits were investigated in the 1960s and 1970s.

In the ancient Egyptian and later Roman eras, it was re-discovered that adding volcanic ash to the mix allowed it to set under water. Similarly, the Romans knew that adding horse hair made concrete less liable to crack while it hardened, and adding blood made it more frost resistant.

After the Roman Empire, the use of burned lime and pozzolan was greatly reduced until the technique was all but forgotten between 500 and the $14^{\text {th }}$ century to the mid- $18^{\text {th }}$ century, the use of cement gradually returned. The canal du midi was built using concrete in 1670 .

Perhaps the greatest driver behind the modern usage of concrete was Smeaton's Tower, The third Eddy stone lighthouse in Devon, England. To create the structure between 1756 and 1759, British engineer John pioneered the use of hydraulic lime in concrete, using pebbles and powdered brick as aggregate.

A method for producing Portland cement was patented by Joseph Aspdin in 1824.Reinforced concrete was invented in 1849 by Joseph Monier. In 1889 the first concrete reinforced bridge was built, and the first large concrete dams were built in 1936, Hoover dam and Grand Coulee Dam.

\section{SCOPE OF THE PROJECT}

The availability of good quality aggregates is depleting day by day due to tremendous growth in Indian construction industry. Aggregates are the main constituents of concrete occupying approximately $75 \%$ of its volume and directly affecting the fresh and hardened properties. Concrete being the largest man made material used on earth is continuously requiring good qualities of aggregates in large volumes a need was felt to identify potential alternative source of aggregate to fulfil the future growth aspiration of Indian construction industry. Use of slag as aggregates provides opportunity to utilize this waste material as an alternative to normally available aggregates.

Based on the experience of work following future scopes are identified:

- Characterization of slag available from various steel manufacturing plants could be done for the comparison of performances of concretes obtained with these slag.

- Collection of data for characterization of such slag wastes generated from all the steel making plants is of extreme importance and could be taken up immediately.

- Study of environmental problems created by such wastes remaining without recycling and proper utilization.

Development of mathematical model based on various parameters to ascertain its strength characteristics in respect of concrete.

\section{MODEL DISCRIPTION}

There is currently no ASTM International standard that specifically addresses the use of ACBFS as an aggregate in concrete. Several countries have previously had separate standards for ACBFS aggregate, but more recently have integrated the information on ACBFS into their standards for concrete aggregates, as summarized in the following sections. The international standards use SI units, and the information related to these standards presented in this section is therefore presented in SI units. The standards discussed address requirements for ACBFS aggregate use in concrete, and limited special mention is made in any of these standards regarding the use of concrete for paving applications.

In this investigation we are going to replace $10 \%$ of cement with metakaolin and coarse aggregate with blast furnace slag with increasing percentages of $0 \%, 10 \%, 20 \%, 30 \%, 40 \%$. And we cast cubes and cylinders at various percentages of replacements and we can find the compressive and tensile strength of concrete

The strength of concrete increase gradually upto $30 \%$ replacement of concrete and the decreases this is mainly due to arrangement and the increase of air voids beyond $30 \%$ replacement. This replacement leads to the reduction of cost of 
construction due to the use of industrial waste as ingredient of concrete. Metakaolin act as mineral admixture and converts calcium hydroxide in to cementicious compound so it leads to strength increment. The cost of slag is very less, by usage of these materials in the concrete improve strength and durability of concrete with low cost.

\section{DESIGN PROCEDURE FOR}

CONCRETEMIX:(IS:456-2000 \&IS:10262-2009)

of IS456-2000, the mix design procedure as recommended in IS $10262-82$ is required to be modified to the extent considered necessary and examples of mix design is worked out.

\section{a) Design stipulations}

$$
\begin{aligned}
& \text { i. Characteristic compressive strength } \\
& \text { required in the field at } 28 \text { days } \\
& \text { i Maximum size of aggregate } \\
& \text { iii. Degree of quality control }
\end{aligned}
$$

\section{b) Tested data for materials}

i.Specific gravity of cement:3.15

ii.comp. Strength of cement at 7 days:Satisfies

iii. Specific gravity of Coarse aggregates:2.62

Specific gravity of Fine aggregates :2.64

Specific gravity of slag :2.45

\section{c) Target mean strength of concrete}

The target mean strength for specified characteristic cube strength is $25+1.65 * 4=31.6 \mathrm{~N} / \mathrm{mm}^{2}$

\section{d) Selection of water - cement ratio}

From IS 456-2000 for moderate exposure the max W/C is 0.5.Min cement content is

\section{$300 \mathrm{~kg} / \mathrm{m}^{3}$}

\section{e) Selection of water content}

From IS method for $20 \mathrm{~mm}$ max size of aggregate, Sand conforming to grading Zone II. Water content per cubic meter of concrete $=186 \mathrm{~kg}$.

\section{f) Determination of cement conten}

$$
\text { Required water content }=186 \mathrm{lit} / \mathrm{m}^{3}
$$

$$
\begin{array}{ll}
\text { W/C ratio }= & 0.5 \\
\text { Water } & =186 \text { lits } \\
\text { Cement } & =186 / 0.5 \\
& =372.00 \mathrm{~kg}
\end{array}
$$

g) Determination of Coarse and Fine aggregate contents We are using Zone II sand and $20 \mathrm{~mm}$ size aggregates. Therefore from IS code the volume of coarse aggregate per unit volume of total aggregate is $\mathbf{0 . 6 2}$

Total volume of concrete $=\mathrm{V}_{\mathrm{a}}+\mathrm{V}_{\mathrm{c}}+\mathrm{V}_{\mathrm{w}}$

Where $\mathrm{V}_{\mathrm{a}}=$ Volume of aggregate

$\mathrm{V}_{\mathrm{c}}=$ Volume of cement

$\mathrm{V}_{\mathrm{w}}=$ Volume of water

$\mathrm{V}_{\mathrm{a}}=1-\left(\mathrm{V}_{\mathrm{c}}+\mathrm{V}_{\mathrm{w}}\right)$

$\mathrm{V}_{\mathrm{w}}=186 / 1000=0.186 \mathrm{~m}^{3}$

$\mathrm{V}_{\mathrm{c}}=372 / 3.15 * 1000=0.118 \mathrm{~m}^{3}$

$\mathrm{V}_{\mathrm{a}}=1-(0.186+0.118)=0.95 \mathrm{~m}^{3}$

Volume of coarse aggregate $=0.695 * 0.62=0.431 \mathrm{~m}^{3}$

Volume of fine aggregate $=0.695-0.431$

$$
=0.264 \mathrm{~m}^{3}
$$

Weight of coarse aggregate $=2.75 * 0.431 * 1000=1185 \mathrm{~kg}$

Weight of fine aggregate $=2.6 * 0.263 * 1000$

\begin{tabular}{|c|c|c|c|c|c|}
\hline \multirow[t]{2}{*}{ Materials } & \multicolumn{5}{|c|}{$\begin{array}{l}\% \text { of slag replacement in coarse aggregate \& } 10 \% \text { replacement } 0 \\
\text { cement }\end{array}$} \\
\hline & $0 \%$ & $10 \%$ & $20 \%$ & $30 \%$ & $40 \%$ \\
\hline $\begin{array}{l}\text { Coarse } \\
\text { aggregate }\end{array}$ & 12 & 10.8 & 9.6 & 8.4 & 7.2 \\
\hline Fine aggregate & 7.03 & 7.03 & 7.03 & 7.03 & 7.03 \\
\hline Slag & 0 & 1.2 & 2.4 & 3.6 & 4.8 \\
\hline Metakaolin & 0 & 0.37 & 0.37 & 0.37 & 0.37 \\
\hline Cement & 3.7 & 3.39 & 3.39 & 3.39 & 3.39 \\
\hline Water & 1.8 & 1.8 & 1.8 & 1.8 & 1.8 \\
\hline
\end{tabular}

The mix proportion becomes

$$
=694.32 \mathrm{~kg}
$$

Hence the Mix is 1:1.8:3.3 (Designed for M25)

\section{Weight proportions:}

The proportions of various materials per cubic meter of concrete are given below

$$
\begin{array}{ll}
\text { Coarse aggregate } & =1200 \mathrm{~kg} \\
\text { Fine aggregate } & =700 \mathrm{k} \\
\text { Cement } & =372 \mathrm{~kg} \\
\text { Water } & =186 \mathrm{~kg}
\end{array}
$$

Table- III will represent the various proportions of materials required for casting of 3 cubes

TABLE IV comparison of test results.

\begin{tabular}{|l|l|l|}
\hline Experiment name & Blast Furnace Slag & Granite aggregate \\
\hline Flakiness index & $1 \%$ & $10.38 \%$ \\
\hline Elongation index & $49.3 \%$ & $46.21 \%$ \\
\hline Impact index & $26.6 \%$ & $11.8 \%$ \\
\hline Specific gravity & 2.45 & 2.75 \\
\hline Water absorption & $1 \%$ & $0.2 \%$ \\
\hline
\end{tabular}

TABLE V. properties of cement and metakaolin

\begin{tabular}{|c|c|c|}
\hline PROPERTY & CEMENT(OPC) & METAKAOLIN \\
\hline Specific gravity & 3.1 & 2.5 \\
\hline Mean grain size $(\mu \mathrm{m})$ & 22.53250 & 2.54 \\
\hline Specific area $\left(\mathrm{cm}^{2} / \mathrm{g}\right)$ & 3250 & $150000-180000$ \\
\hline Colour & Dark grey & Ivory to cream \\
\hline Silicon dioxide(sio2) & 20.25 & $60-65$ \\
\hline $\begin{array}{c}\text { Aluminium } \\
\text { oxide(AL2O3) }\end{array}$ & 5.05 & $30-34$ \\
\hline Iron oxide(Fe203) & 3.16 & 1.00 \\
\hline Calcium oxide $(\mathrm{CaO})$ & 63.61 & $0.2-0.8$ \\
\hline $\begin{array}{c}\text { Magnesium oxide } \\
(\mathrm{MgO})\end{array}$ & 4.56 & $0.2-0.8$ \\
\hline Sodium oxide $(\mathrm{Na} 20)$ & 0.08 & $0.5-1.2$ \\
\hline $\begin{array}{c}\text { Potassium oxide } \\
(\mathrm{K} 2 \mathrm{O})\end{array}$ & 0.51 & - \\
\hline Loss on ignition & 3.12 & $<1.4$ \\
\hline
\end{tabular}




\section{A. Casting of cubes}

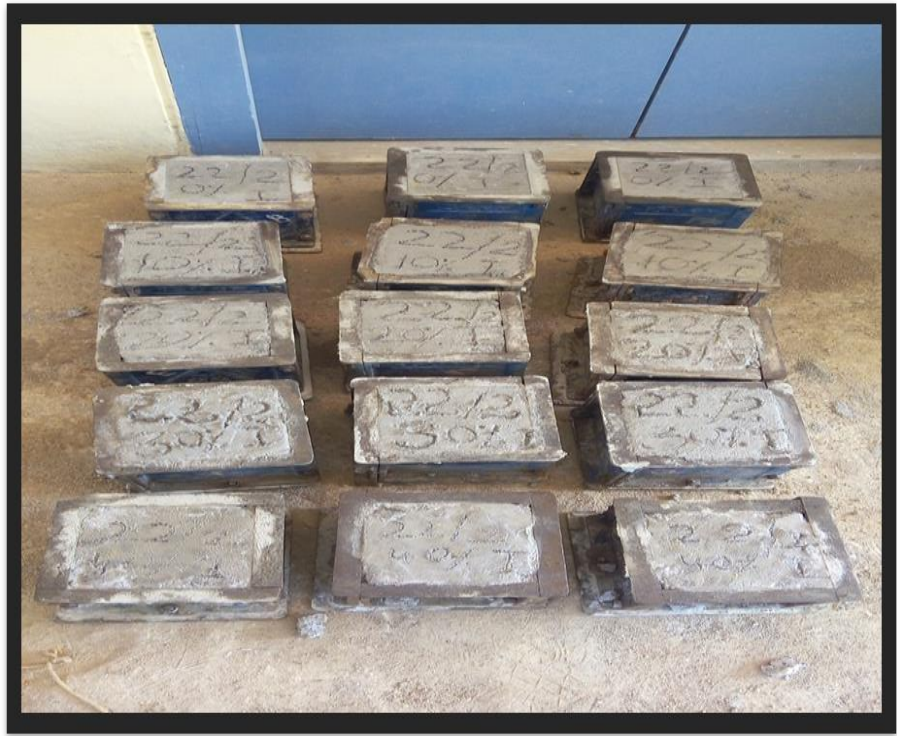

Fig. 3 samples of cubes for each replacement for both 7 days and 28 days so totally we cast 30 cubes.

\section{B. Casting of cylinders}

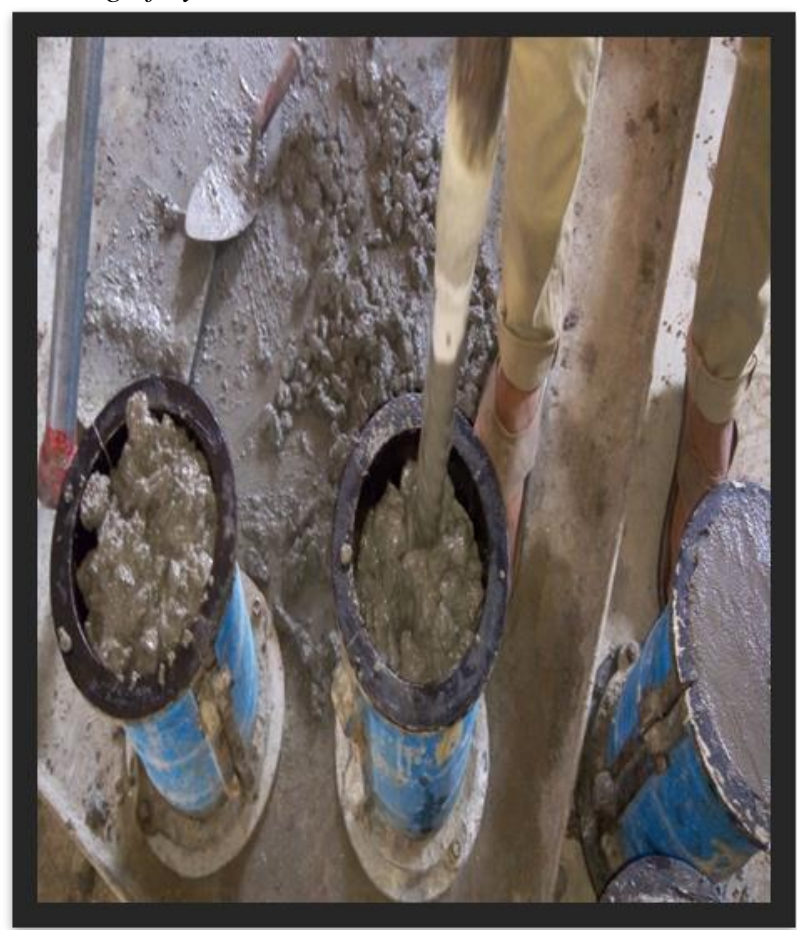

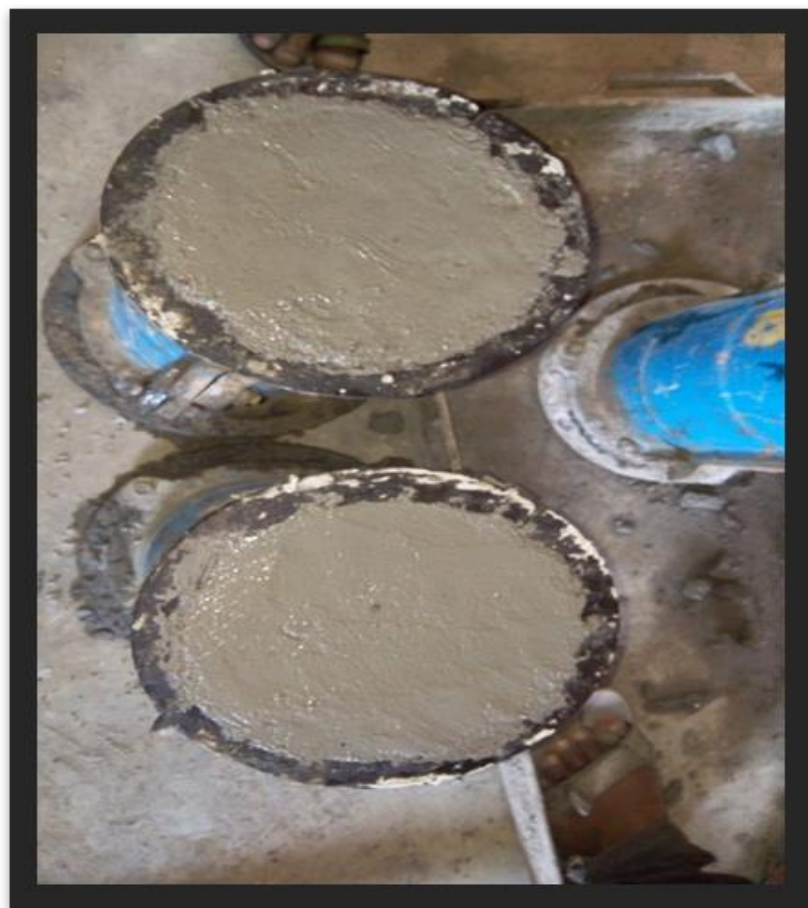

Fig. 4. Concrete Placing and compacting

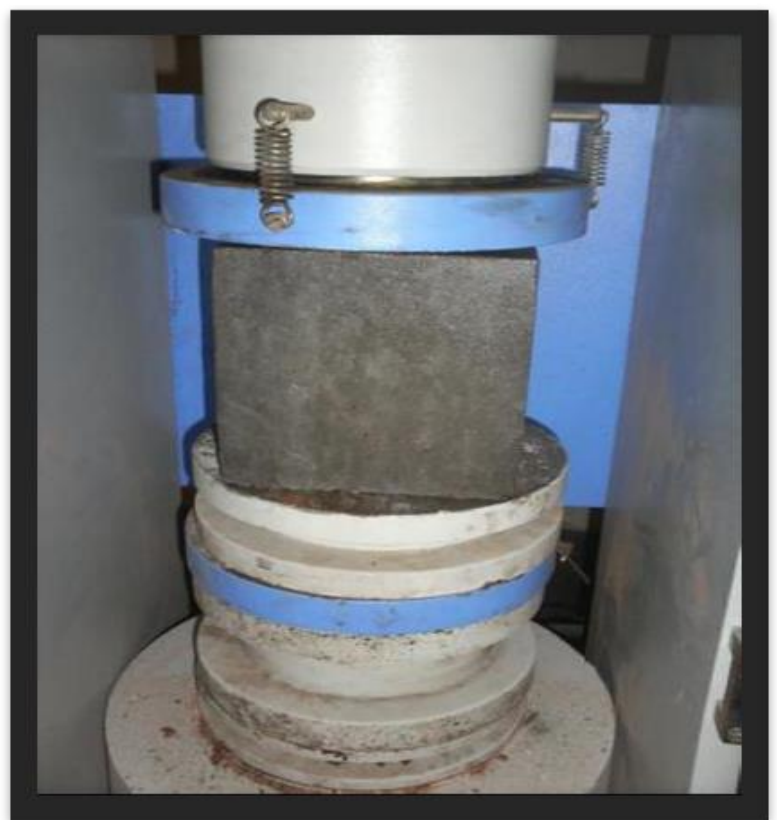

Fig. 5. Load acting on cube to find compressive strength 


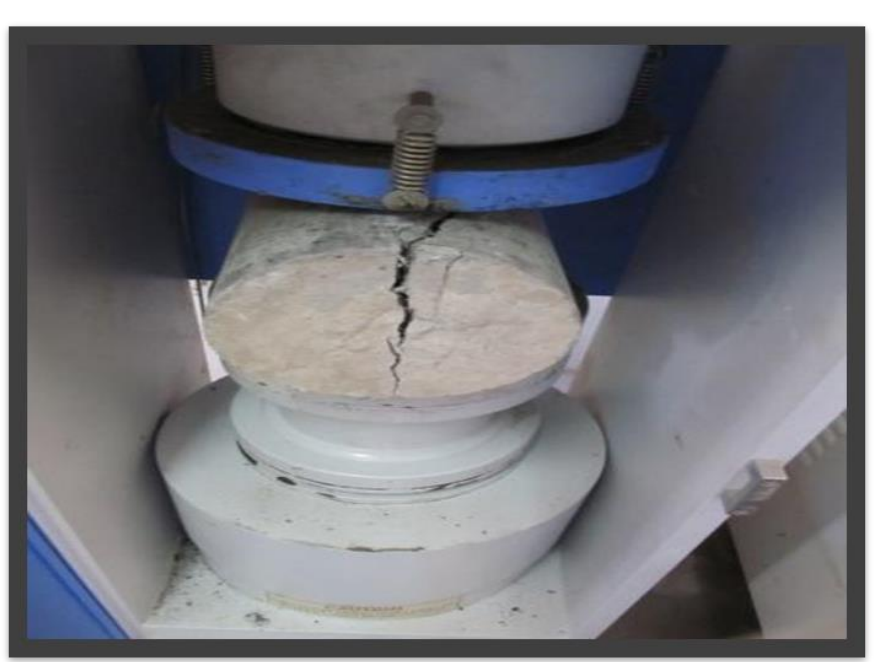

splitting tensile strength

\section{RESULTS AND DISCUSSIONS}

Compressive strength of cubes for each \%replacement of slag for both 7 days and 28 days are given below in Table VII

\begin{tabular}{|l|c|l|c|c|}
\hline \multirow{2}{*}{ Mix } & \multirow{2}{*}{$\begin{array}{c}\text { \% of slag } \\
\text { replacement }\end{array}$} & \multirow{2}{*}{ \%op metakaolin } & \multicolumn{2}{|c|}{$\begin{array}{c}\text { Compressive } \\
\text { strength(N/mm }{ }^{2} \text { ) }\end{array}$} \\
\cline { 4 - 5 } & & & $\mathbf{7}$ days & $\begin{array}{c}\mathbf{2 8} \\
\text { days }\end{array}$ \\
\hline M25 & O & 10 & 16.4 & 27.8 \\
\hline M25 & 10 & 10 & 20.1 & 27.9 \\
\hline M25 & 20 & 10 & 21.6 & 29.6 \\
\hline M25 & 30 & 10 & 23.6 & 32.1 \\
\hline M25 & 40 & 10 & 22.3 & 30.8 \\
\hline
\end{tabular}

Tensile strength of cylinders for each \% replacement of slag and metakaolin for both 7 days and 28 days are given below in Table VI

\begin{tabular}{|c|c|c|c|c|}
\hline \multirow{2}{*}{ Mix } & \multirow{2}{*}{$\begin{array}{l}\text { \% of slag } \\
\text { replacement }\end{array}$} & $\begin{array}{l}\text { \% of metakaolin } \\
\text { replacement }\end{array}$ & \multicolumn{2}{|c|}{$\begin{array}{c}\text { Tensile } \\
\left(\mathbf{N} / \mathbf{m m}^{2}\right)\end{array}$} \\
\cline { 3 - 5 } & & & 7 days & $\begin{array}{c}\text { strength } \\
\text { days }\end{array}$ \\
\hline M25 & 0 & 10 & 1.88 & 2.61 \\
\hline M25 & 10 & 10 & 2.05 & 2.65 \\
\hline M25 & 20 & 10 & 2.18 & 3.32 \\
\hline M25 & 30 & 10 & 2.4 & 3.55 \\
\hline M25 & 40 & 10 & 2.03 & 3.14 \\
\hline
\end{tabular}

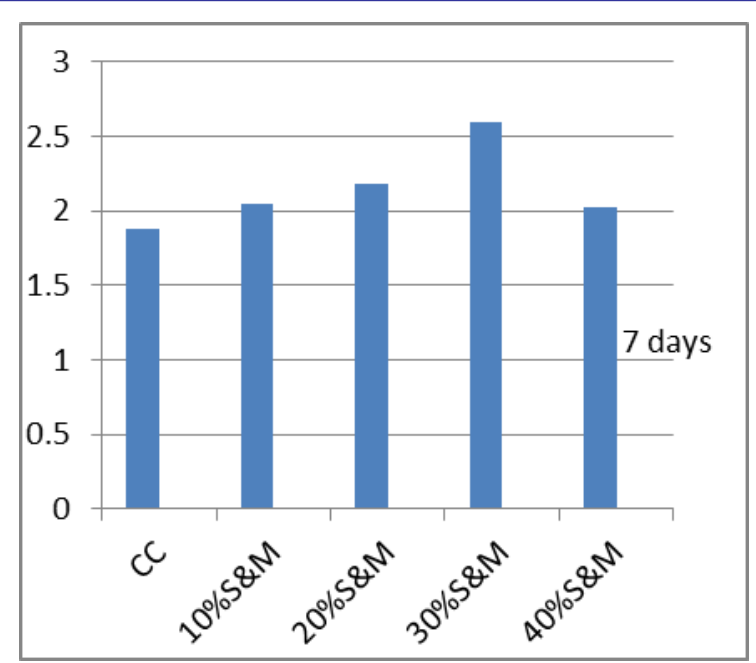

Graph - 7 days tensile strength results

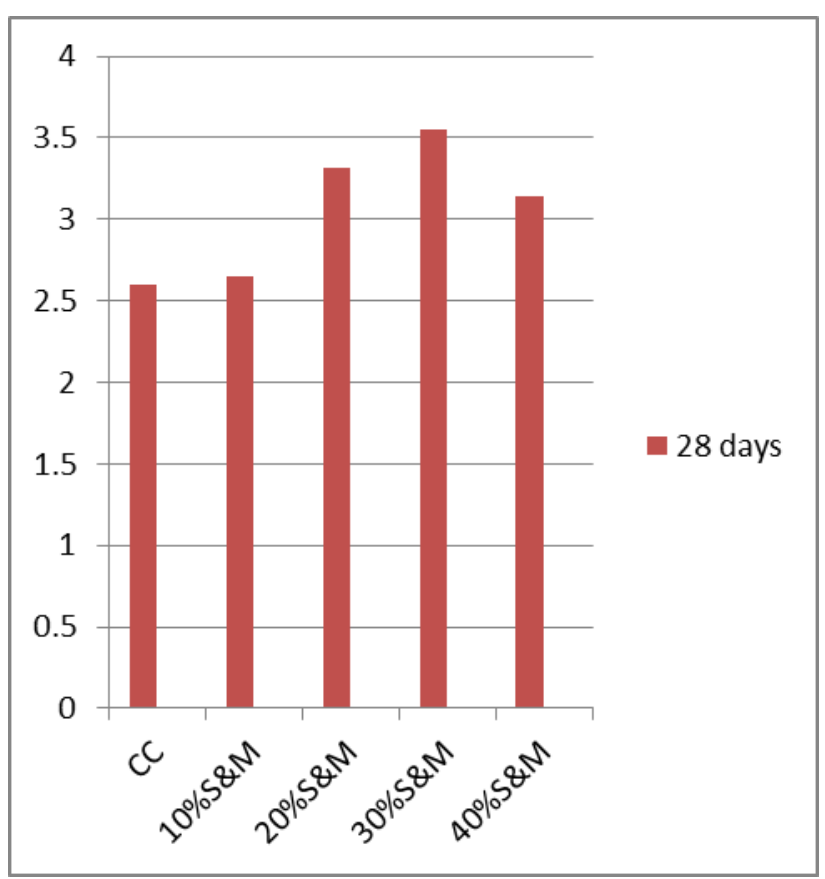

Graph - 28 days tensile strength results

In the above graph the $\mathrm{X}$-axis indicates $\%$ of slag and metakaolin replacement in coarse aggregate and cement respectively and $\mathrm{Y}$-axis indicates compressive strength.

We got optimum value at $30 \%$ replacement of slag in coarse aggregate and $10 \%$ replacement of cement with metakaolin

1. The increase of compressive strength is mainly due to the surface roughness leads to proper bonding.

2. Strength reduction most likely due to increased amount of air voids due to improper arrangement of coarse aggregate beyond the limit of presence of slag.

3. Most research agrees that metakaolin act as mineral admixture leads to the improved properties of concrete.

4. The reduction of strength after $30 \%$ is due to the increase of the ferrous content in the concrete. 


\section{CONCLUSION}

In this investigation we are going to replace coarse aggregate with blast furnace slag and $10 \%$ of cement with metakaolin. Blast furnace slag is a by-product and using it as a aggregate in concrete will might prove an economical and environmentally friendly solution in local region. The strength of concrete increase gradually upto $30 \%$ replacement of concrete and the decreases this is mainly due to arrangement and the increase of air voids beyond $30 \%$ replacement. This replacement leads to the reduction of cost of construction due to the use of industrial waste as ingredient of concrete. Metakaolin act as mineral admixture and converts calcium hydroxide in to cementicious compound so it leads to strength increment. The cost of slag is very less, by usage of these materials in the concrete improve strength and durability of concrete with low cost.

- The physical and chemical properties of GBFS are suitable for the production of concrete mix.

- The compressive strength and split tensile strength are higher for replacement of $30 \%$ of GBFS and replacement of cement with $10 \%$ Meta Kaolin.

- The compressive strength and split tensile strength are lower for $0 \%$ replacement.

- The results showed that using Meta Kaolin and increasing $\%$ of flash with GIBFS an improvement in the impermeability of concrete.

The replacement of cement by MK leads to decrease in pore space.

\section{List of Indian standards referred}

\section{REFERENCES}

1. Is: 269-1958 specification for ordinary, rapid-hardening and low heat Portland cement (revised and reprinted, aug.1965)

2. Is: 10262-1982, recommended guidelines for concrete mix design, $4^{\text {th }}$ reprint, 1996.

3. Is: 456-2000, Indian standard plain and reinforced concrete code of practice, 4threvisio,

$1 \mathrm{st}$ reprint/sep, 2000.

4. Is: 12269-1987 (reaffirmed1999), specification for 53 grade ordinary Portland cement, first reprint, September, 1993.

5. Is: 2386-1963 tests for a(all parts),method of aggregates for cement.

\section{List Of Journals referred}

[1] Abdulaziz I. Al-Negheismish, Faisal H. Al-Sugair and Rajesh Z. AlZaid (1996), 'Utilization of Local Steelmaking Slag in concrete', Journal of Environmental science of sustainable society, Vol. 1, pp. 39-55,

[2] Anastasiou E. and Papayianni I. (2006), 'Criteria for the Use of Steel Slag Aggregates in Concrete', Measuring, Monitoring and Modeling Concrete Properties.

[3] Barry M.S., Ibrahim M., Maslehuddin M., Al farabi M.S., Shameem M., (2002), 'Comparison of properties of steel slag and crushed limestone aggregate concretes', Construction and Building Materials, Vol. 17, pp 105-112.

[4] Biju Mathew, Dr Freeda Christy C, Dr. Benny Joseph and Anuragi.P, An Experimental Study on Properties of Cement Mortar by Replacement of Natural Sand with Manufactured Sand. International Journal of Civil Engineering and Technology (IJCIET), 7(4),2016, pp.483-490.
[5] Dubravka Bjegovic', Goran Vrhovac, Ivanka Netinger, (2011), 'Utilization of steel slag as an aggregate in concrete', Materials and Structures9s.

INTERNATIONAL STANDARDS FOR USE OF AIRCOOLED BLAST FURNACE SLAG IN CONCRETE

\section{Japanese Standards}

The Japanese Industrial Standard JIS A 5011-1977, AirCooled Iron Blast Furnace Slag Aggregate for Concrete (JIS 1977), which has not been withdrawn, specified the following properties for ACBFS coarse aggregate to be used in concrete: - Two classes of aggregate, A and B, are defined in the standard. The following properties are described for the two classes: (a) specific gravity in dry conditions-2.2 minimum for Class A and 2.4 minimum for Class B; (b) water absorption- 5 percent maximum for Class A and 4 percent maximum for Class B; (c) mass per unit volume of aggregate $-1.25 \mathrm{~kg} / 1$ minimum for Class $\mathrm{A}$ and $1.35 \mathrm{~kg} / \mathrm{l}$ minimum for Class B. This standard does not indicate situations where Class A and Class B aggregates are to be used, but it is evident that Class B is of a higher grade than Class A.

- The maximum limits for the following four chemical components are specified: Calcium Oxide $(\mathrm{CaO})-45$ percent maximum; Sulfur (as S)-2 percent maximum; Sulfur Trioxide (as SO3) -0.5 percent maximum; Iron (as $\mathrm{FeO}$ ) - 3 percent maximum. The standard describes the analytical procedure for determining these components.

- The standard describes the immersion test that is to be performed on the aggregates. The immersion test is performed by immersing 30 pieces of aggregate that are retained on the $10-\mathrm{mm}$ sieve in water for 2 days. At the end of the test, the aggregates should be free from cracks, decomposition, muddiness, and dusting.

- The standard describes the procedure for performing an irradiation test by ultraviolet light on the aggregates. In this test, 10 aggregate particles are crushed with a hammer and chisel to expose fresh fracture faces and subjected to an ultraviolet light having a wavelength of $360 \mathrm{~nm}$. The aggregates are regarded as being acceptable if the aggregates do not radiate or shine evenly in violet shades.

- The standard describes gradation limits for the following five aggregate classes: (a) nominal aggregate size from 40 to 5 $\mathrm{mm}$, (b) nominal aggregate size from 40 to $20 \mathrm{~mm}$, (c) nominal aggregate size from 25 to $5 \mathrm{~mm}$, (d) nominal aggregate size from 20 to $5 \mathrm{~mm}$, and (e) nominal maximum aggregate size from 15 to $5 \mathrm{~mm}$.

A newer Japanese Standard, JIS A 5011-1:2003Slag Aggregate for Concrete-Part I: Blast Furnace Slag Aggregate, was published in 2003 (JIS 2003). This is a detailed document describing the use of both ACBFS as coarse aggregate and rapidly-cooled blast furnace slag as fine aggregate. With regard only to ACBFS, the following items are presented:

- The chemical composition and physical and chemical properties of ACBFS coarse aggregate are shown in table 20. Each criterion is linked to a test method presented in the document.

- There are two classes of ACBFS, Class L and Class N, of which Class $\mathrm{N}$ is of higher quality. These are separated by oven-dried density, absorption, and bulk density. Japan's 
Standard Specifications for Concrete Structures-2007 (JSCE 2010) states that generally Class N ACBFS is used, with Class $\mathrm{L}$ aggregate "used only in concrete whose freeze-thaw resistance need not be so high and characteristic compressive strength is less that $21 \mathrm{~N} / \mathrm{mm} 2$."

- Maximum total sulfur content is set at 2.0 percent and maximum percent of acid-soluble sulfates is 0.5 percent (see also ASTM C114).

- Various tests are conducted to ensure stability of the ACBFS and uniformity. Detailed reporting requirements are provided in the standard. Japan's Standard Specifications for Concrete Structures-2007(JSCE 2010)recommends that testing should be conducted prior to construction and at least monthly during construction.

\section{British/European Standards}

The British Standard BS 1047-1983, Air-Cooled Blast Furnace Slag Aggregate for Use in Construction (BS 1047 1983), which was withdrawn in 2004, specified detailed requirements for ACBFS coarse aggregate when used in concrete. The following is a summary of the requirements for ACBFS aggregate used in concrete (BS 1047 1983):

- Iron pellets should not be present in a sufficient quantity to cause surface spalling or staining.

- The bulk density of the aggregate should not be lower than $1,100 \mathrm{~kg} / \mathrm{m} 3$ (when determined according to BS 812). The sample used for determining the bulk density should pass the 14-mm sieve and be retained on the $10-\mathrm{mm}$ sieve.

- The stability of the aggregate against iron unsoundness must be established by testing the aggregate. The test is performed by immersing not less than 12 pieces of aggregate that pass the $40-\mathrm{mm}$ sieve but are retained on the $20-\mathrm{mm}$ sieve in distilled or deionized water for 14 days. Aggregates that develop no cracking or disintegration are regarded as being free from iron unsoundness. The standard describes the detailed procedure for performing this test.
- The aggregate should be tested for "falling" or dicalcium silicate unsoundness. The standard describes the procedure for performing this test. In the test procedure, the aggregate is analyzed chemically to determine the percent content by mass of $\mathrm{CaO}, \mathrm{MgO}, \mathrm{SiO} 2, \mathrm{Al} 2 \mathrm{O} 3$ and $\mathrm{S}$ (total). To pass this test, the percentage of $\mathrm{CaO}$ must meet the following criteria:

The standard indicates that ACBFS aggregate that fails this criterion is not necessarily unsound, stating the decision as to whether the aggregate is unsound should be made based on the results from the microscope test. The procedure for performing the microscope test is described in the standard. In this test, suitable samples are prepared and polished and then etched in a magnesium sulfate solution and examined under a metallurgical microscope.

- The total sulfur content in the aggregate should not be greater than 2 percent, and the percentage of acid-soluble sulfates expressed as SO3 should not be greater than 0.7 percent. 